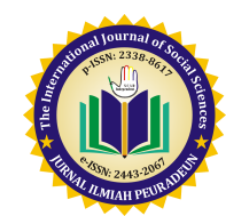

\title{
FEDERALISM CRITICAL ARGUMENTS AS THE TRANSFIGURATIONS OF NIGERIAN FEDERALISM
}

\author{
Hilary Achinike \& Stephens Ogbonna \\ Department of Political Science, University of Nigeria, Nsukka, Nigeria \\ Email: achi.hilary1970@gmail.com
}

\begin{abstract}
The debate concerning Nigeria's political life has, in recent years, pervaded several fora as Nigeria's political life remains under the shadow of an enigma. The basic tenets of federalism touched by a global wind of democracy, quite forceful in some regions of the world, are said to be a field and sweeping across all continents. But in contemporary Nigeria, as in Africa generally, authoritarianism reigns. Federalism critical arguments hold, in spite of its many global 'bastard' incarnates which in Nigeria shows as weak, emaciated and a pitiable thing. This paper argues that the body politic of Nigeria is congenially unreceptive to the reproductive seeds of a largely potent federalism. It is this 'unreceptive environment' that this paper has characterized as the transfigurations of Nigerian federalism.
\end{abstract}

Keywords: Nigeria, Federalism, Transfigurations, Politics, Critical 


\section{A. Introduction}

Federalism was adopted in Nigeria as a compromise device to help the country avoid the prospects of piecemeal independence from the British. Some contend that it was a clever imposition by the British to appease the reactionary North. Despite what may or may not have been the real reasons or causes, four things are incontrovertible. One, Nigerian federalism was not arrived at through social contract or plebiscite. It was a model agreed to by a handful of political leaders at the pre-independence London constitutional conferences. Two, Nigerian federalism is very sick, unbalanced and lopsided especially in terms of the over-centralization of power. Three, national integration has remained an illusion at best, even after forty-nine years of independence, with few prospects for change. Ethnicity has been elevated by some people to the level of religion and so Nigeria has remained a state rather than a nation. Four, pronounced injustices exist in the Nigerian federation.

It is largely these facts that inspire the advocacy of political autonomy as a platform for finding answers to such questions as: Where do we go from here? How dowe best live together? Implicit here are also the issues of resource control and management agitation. These issues cannot be wished away or glossed over. They will continue to haunt Nigeria until it courageously and sincerely addresses them and finds meaningful answers.

In general terms, one of the variables in this equation, apart from a civic political culture that connects the democratic idea and democratic practice, is political restructuring. This concept, in particular, means different things to different political leaders in contemporary federal systems. This is especially evident in those countries (including post June 12, 1993 Nigeria) where most nationalities seek a radically restructured federation in which the power of the federal state is reduced.

Such political restructuring appears to be informed by the poor praxis of an admittedly formal federal system. In other words, the glamour for restructuring is more stringent in countries with a federal form of government - and perhaps also a federal constitution but with a 
unitary practice. As Williams Riker (Stepan, 1997) has noted, what counts is not the rather trivial constitutional structure, but rather the political and economic culture.

The political and economic culture of a federal system can be antithetical to the wishes, aspirations and goals of individuals and nationalities. This is in relation to the aggregate premises - both value and factual - of governance to varying degrees depending on the nature and character of the federal state. Divergences between the federal system and the inclinations of citizens and groups brings into focus Linz (1997:21) claim that "federalism can only assure that nobody could be fully unhappy but certainly not that everybody will be happy with the solution".

However, when a neopatrimonial federal logic makes only state officials and their acolytes happy, and cuts across ethnic, religious, regional, class and gender cleavages, pockets of dissent, dissidence and contestations will naturally emerge. Following this, it becomes necessary to recognize that the crises in Nigerian federalism are not just about bickering 'tribes' but also about social injustices. Thus, although federalism has brought several nations together within the Nigerian polity, federal practice has hardly been able to keep them that way happily.

In what follows, we examine the specific utterances and attitudes of political leaders that clearly demonstrate Nigerian federalism to be a peculiar manifestation of this form of governance.

\section{B. Method}

This research adopts a philosophical analysis which examines the language involved in any discourse. The essence of this method shows that our understanding of philosophical issues, as well as their intelligent examination, depends to a large extent on our ability to understand the proper use of language. This perspective underscores the intent of this research to analyze the utterances and attitudes ofNigerian political leaders against the background of a civic culture that is germane to promoting federalism and constitutionalism. 
This research also employs logical analysis and the eliciting of argument by analogy. These involve the validation of argument and conclusion using simple methods of inductive and deductive reasoning. Such must be the case because of the very nature of the philosophical enterprise in the contemporary milieu. Political philosophy is a rational enquiry into all that concerns man and his life in relationship with his fellow men in society. It is the rational study and evaluation of the elements of the state culminating in an enquiry into ideals. The tools of the outlined methods are therefore central to evaluating the actions of men in order to expose their implications. The primary materials used for this research are collated utterances and speeches made by specific Nigerian leaders in one public forum or the other. The attitudes of select other leaders are also included. The consequences of these utterances, speeches and attitudes are then evaluated against the views of experts on federalism especially in terms of the pre-requisites for the successful operation of federalism.

Since the overriding method used in this research is descriptive, it renders unproductive the use of quantitative research instruments. In view of this, the reliability of the materials used for this research depends on the power of the descriptive analysis to correspond with the existent Nigerian realities. As such, the collated utterances, speeches, and the attitudes are not mere conjectures allegedly credited to those who either made or exhibited them, but authoritative document-materials in the public domain.

\section{Transfigurations of Nigerian Federalism}

Before the 1885 Berlin conference, the elements that were to become Nigeria remained autonomous political units, each one rich in culture and sophisticated socio-political systems and economically viable. These units counted the Amayanabos, Obis, Obas, Olus, and Emirs among the heads of their different governments.

It should be noted that these different units came under British imperial colonial rule on an individual basis. Separate treaties were also 
entered into between indigenous rulerships and the British so as to give legal backing to the new colonial dispensation. Although all of this predated the birth of Nigeria, these events continue to have significance for contemporary attempts at federalism.

In 1914, Lord Lugard amalgamated the disparate Northern and Southern provinces, each one comprising sophisticated indigenous rulerships, into a single Nigeria. This move was orchestrated purely for the administrative convenience of the colonial administration and the marriage "ceremony" that gave birth to Nigeria was deemed an amalgamation. This was portentous for, in chemical terminology, Nigeria has since functioned as an amalgam and not a compound in terms of its evolution (or lack thereof) to nationhood. Nigeria's permanent amalgam state has great import in the quest for Nigerian federalism.

Jagun (1993) has rightly argued that "the genesis of today's discord over the fate of Nigeria was sown in the 1914 arbitrary amalgamation as well as the error of block independence granted in 1960 to a geographical entity called Nigeria which has no legal treaty with the crown (British)". Abubakar Tafawa Balewa (2001), contributing as Honorable member of the Legislative council in 1947, expressed similar sentiments noting that, "since the amalgamation of the Southern and Northern Provinces in 1914, Nigeria has existed as one country only on paper. It is still far from being united".

Elder Statesman, Obafemi Awolowo (1947:133), opined that "Nigeria is not a nation. It is a mere geographical expression. There are no Nigerians in the same sense as there are 'English', 'Welsh' or 'French'. The word 'Nigeria' is merely a distinctive appellation to distinguish those who live within the boundaries of Nigeria from those who do not". He further observed that sectional "incompatibilities tend to grow in size as those concerned become more educated and civilized". This trend has continued several years after the sage made the observation and so what guarantee do we have that it will not be so in five or ten years to come if we fail to address the cosmetic farcical unity surrounding the deeper viruses of disunity? 
Paden (1986), the biographer of the Sardauna of Sokoto, Sir Ahmadu Bello, recounted an encounter between the Rt. Honourable Nnamdi Azikiwe and the Sardauna during one of the constitutional conferences on independence. Zik was said to have suggested to the Sardauna thatboth should forget their differences and work together for Nigeria's unity. The Sardauna was quoted in his response as saying, "No, let us understand our differences. I am a Muslim and a Northerner. You are a Christian and a Southerner. By understanding our differences we canbuild unity in our country". Can anyone fault the Sardauna for such a perspective? While on the surface the statement seems to convey parochialism, it succinctly and effectively brings to the fore one of our greatest weakness, that of playing the ostrich when faced with crucial national challenges. In the end, this approach fuels our own disunity. It is possible further, to argue that the Sardauna's position is encapsulated in the contemporary demand for a National Conference to debate the National Question. Other comparable agitations include the quest for Rotational Presidency and Resource Control and Management. The earlier we accept the inevitability of these changes the better it would be for Nigeria.

These leaders and scholars have not been alone in their analysis of the consequences of early twentieth-century British decisions for Nigeria. In "My Life: An Autobiography", Sir Ahmadu Bello considers the Lugard's amalgamation of 1914 to be 'the mistake of 1914' (David-West 2001) while in 1948 Tafawa Balewa posited the amalgamation as a "British intention". Lt. Col. Odumegu Ojukwu, at a meeting of National Conciliation Committee led by Chief Obafemi Awolowo (1968:28) on May 6, 1967, reflected that: "The question which seems to bother us is the question of Nigerian unity. Can there be unity in Nigeria? To these two questions, the answer is No. Throughout there has been association not unity. The North has made it abundantly clear that no association which they are not controlling is acceptable to them". Graham-Douglas (1985), contributing at the 1983 National conference on Nigerian independence contended: "Ours is a plural society in which the desire for inter-group co- 
existence within a distinct territorial-constitutional framework tends to be prejudiced by inter-group animosities and suspicions, by the bogey of superiority, by the feelings of greater suitability for the fulfillment of roles of national leadership, and so on".

That year 1914 has continued to jinx all processes involved in the political evolution from country to nation, from disunity to unity, from amalgamation for administrative convenience to true federalism. Perhaps, it is time to ask if the Lugardian amalgamation of 1914 was intended to produce a political cohesion and integration that would eventually metamorphose to nationhood or if Lugard followed a hidden agenda. Elaigwu (1985) in "Nation-Building and Political Development in Nigeria: The Challengeof Unity in a Heterogeneous Society", a paper delivered at the National Conference on Nigeria Since Independence observes: "if the amalgamation of 1914 was aimed at a political fusion of the North and the South, it did not have the objective of building a united state, nor did the British envisage, by the remotest of imagination, that a 'nation' would emerge from the geopolitics".

Grave doubts concerning Nigerian unity and the desires of the British were also expressed by Sir Ahmadu Bello, the Sardauna of Sokoto, in a 1953 contribution to the timetable for self-government. The Sardauna argued that "it is true that the politicians always delight in talking loosely about the unity of Nigeria. Sixty years ago, there was no country called 'Nigeria'. What is now Nigeria consisted of a number of large and small communities' all of which were different in outlook and beliefs. In 1914, the North and the South were amalgamated although the administrations of the two sections were strictly different. Since then, no serious attempt has been made by the British or by the people themselves to come together and each Section has looked upon the other with suspicion and misgivings".

Finally, Lt. Col. Yakubu Gowon's National Broadcaston August 1, 1966, as the Supreme Commander and Head of the Federal Military Government, was a landmark query of Nigerian unity. He pronounced, "I now come to the most important point of this statement; I am doing it 
conscious of the great disappointment and heart-break it will cause all true and sincere lovers of Nigeria, and of Nigerian unity, both at home and abroad, especially our brothers in the Commonwealth. As a result of the recent events and the previous similar ones I have come to strongly believe that we cannot honestly and sincerely continue in this wise, as the basis for trust and confidence in our unitary system of government has been unable to stand the test of time... Suffice it to say that putting all consideration to the test, political, economic as well as social, the basis for unity is not there, or is so badly rocked not once but for many times" (David-West, 2001).

Given the above doubts about Nigerian unity, from "faulty amalgamation of 1914" and "differences of the North and South" to "the basis of unity is not there", on what premise(s) is the argument for the rejection of rotational presidency based? Our brand of federalism, its chequered historical antecedents and the quest for political autonomy should be addressed in the light of the realities outlined above.

It should be noted that all things being equal, federalism offers an ideal model of government for a plural society. And Nigeria, with at least 374 ethnic groups certainly qualifies for federalism should we find the political will to embrace the philosophy. Nonetheless, some argue that federalism was an imposition by the British government and perhaps not without some sinister motives - a hidden agenda to plant discord and disunity after independence so as to succeed in its policy of "Divide and Rule".

The British government was not new to experimenting with federalism. It had been the model for several heterogeneous societies once under its rule. The first of such experiments was Canada in 1867 and subsequently Australia. However, in the cases of Canada and Australia a measure of similarity in blood bond, language or culture existed - one of the key conditions of federalism outlined by Appadori (1968).

Nigeria's march towards constitutional democracy and federalism has been a chequered one. The Richard Constitution of 1947 was a watershed moment in terms of increasing political awareness. However, 
in place of resulting cohesive action Nigeria remained divided. Geo-ethnic rivalry was still the order of the day and this form of organization was fuelled considerably by the regionalism and self-government of the 1950s. However, given the acknowledged socio-political and economic asymmetry, especially in the context of ethnic geo-politics, federalism emerged as attractive. In the process several compromises were made, largely with a view to achieving corporate or collective political independence, what Dokun Jagun has called "block independence".

The politics of minority groups also surfaced at this time and were articulated much more forcefully. Suspicion and fear of domination by majority groups were common and far from being figments of a xenophobic imagination. Such fears were founded in experience at the time as they are today and remain a potent cause of disunity. As a result we had the Mid-West State Movement, the Calabar-Ogoja-Rivers (COR) Movement and the Movement for Middle-Belt State. At the time of independence on October 1, 1960 these fears and suspicions were accentuated rather than diminished as both macro and micro geo-ethnic imbalances became more and more apparent. This potent cause of disunity is still very much present today and has, in fact, mutated into a number of more venomous forms.

The 1960 and 1963 Constitutions devolved tremendous powers to the regions, which unto themselves, became fulcrums of political power. Regionalism was nurtured or realized to the extent that the equilibrium between centrifugal and centripetal political forces, which true federalism addresses, became much more academic than real. This continues today.

The 1963 population census, like the 1914 amalgamation, continues to haunt present-day attempts at federalism. The census recorded the North as having $54 \%$ of the population thereby giving the North a considerable demographic advantage. In a political system which gave "one man one vote" this translated into a permanent numerical dominance by the North in the powerful Lower House of the central government. The South saw it as political "419" (deception). Expressed mathematically the Nigerian political equation thus became: 


$$
\mathrm{N}=\mathrm{E}+\mathrm{W}(\text { North=East }+ \text { West })
$$

The South rejected and still rejects the North as more populated. Suspicions that the 1963 census was a 419, and its subsequent rejection by the South, have since been verified in the revelations of Harold Smith, a former British Colonial officer in Nigeria. He accepted that the 1959 federal elections and the 1963 population census were rigged by the British government in favors of the North (Akinkuotu, 2005:33). The consequences of the politicization of the census have been far reaching and even the most recent census in 2006 has not been free from controversy.

The North-South dichotomy grows with time, fuelled by Southern suspicions that the North has a hidden agenda, which includes always producing political leadership at the federal level.

\section{Minorities and the Nigerian Federation}

There can be no multi-ethnic society without a minority group or groups and a majority group. Furthermore, it could be argued that the stability of any polity is measured by how it treats its minorities. That a chain is as stable as its weakest component is incontrovertible. As such, Nigerian federalism will continue to experience considerable strain unless and until the minority question is addressed.

Federalism as a political philosophy aims to createharmony from intrinsic or inherent political, social and economic asymmetry vis-a-vis ethnic heterogeneity. To have a situation of masters and servants, or a situation of graduated citizenship is a negation of true federalism. In 1980, Adamu Ciroma who was to become Minister of Industry in the Sani Abacha government was quoted as threatening that any ganging up by minorities would be met with counter and drastic reaction by the majority groups (Hausa-Fulani) (Elaigwu, 1985). This is common in Nigeria's form of federalism. It appears as though Ciroma has conveniently forgotten that oil, which accounts for more than $90 \%$ of federal foreign revenue and over $80 \%$ of the total national budget, is derived from the minority areas of the federation. Here we can observe another unsettling manifestation of 
disunity in Nigerian federalism -the public arrogance of dominant ethnic groups which looks very much, on the surface at least, like the tyranny of the majority. Awa (1993) highlights that "discrimination shown towards Nigerian citizens by some ethnic elite groups has grown in scope... All these reinforce in the mind of the average person a feeling of rejection and dampen his loyalty to the nation, leaving the nation severely segmented and weak".

In 1953 and 1966, the North voted in favour of confederation. On April 24, 1967 in a letter to Col. R.A. Adebayo, then Military Governor of the Western Region, Obafemi Awolowo argued that "the most realistic approach to our Constitutional problems, therefore, if we are to save the federation from complete disintegration, and the constituent units from mutual destruction, is to embark now on a four or five year venture of confederation" (1968: 8). Decree 8 of 1967, for all practical purposes, created a veritable confederation.

The strident call for a national conference to address the national question is perhaps the strongest evidence yet that all is still not well with Nigerian federalism. The advocacy of political autonomy is a strong marker of the over-patronization of a section of the federation. It is also a marker of the differences and diversities of the peoples of Nigeria in terms of culture, language, and kinship. To talk about federalism without national integration is, as the above observations have shown, gibberish at best. Political autonomy is a way of nurturing the will and commitment to forging nationhood.

Ali Mazuri lists four imperatives for national integration: coexistence, contact, compromise and coalescence. We have mutually coexisted. We have had mutual contact. We have had some measure of compromise from time to time in spite of inflammatory anti-unity statements by some. We have however, not coalesced and this remains crucial to the founding of true nationhood.

Nigeria's is not a healthy federalism as it has long been plagued by "infection" from the "viruses" of anti-federalism. As such, it must be tended carefully and tenderly if it is to survive contemporary strains and the stresses. 
Given this frail federalism, we cannot fail to agree with Jagun when he posits, "but we had better be true to admit that this union of sorts is bound to burst at the seams if left untendered. The signs are with us" (David-West 2001). As it now stands, Nigeria's federalism could be described as farcical or a federalism façade being manipulated for self-serving ends. This manipulation is evidenced in the jealously guarded over centralization of power at the federal level, especially by those who stand to gain from such an anti-federal or "unbalanced and lopsided" design (Nigerian Tribune, 1992).

\section{E. Conclusion}

Eminent scholars with a progressive world view and familiarity with contemporary political trends continue to caution the country against accepting its current brand of federalism. For instance, Adekanye (1992) while admitting that "there is a strong desire among the diverse elements in the country to remain together", warned "we can no longer afford to take the unity of Nigeria for granted as something finally sealed and forever indissoluble". Madunagwu (1992) argued "preaching peace among Nigerians is useless and sometimes opportunistic and hypocritical". He insists that "the basis of discontent and discord must be removed". Awa (1993), in his three-piece "Thoughts on Nigerian Federalism", points to contemporary events in the Soviet Union, Canada, Yugoslavia and Czechoslovakia and cautions Nigerians and their leaders to be mindful of the consequences of disunity.

From these weaknesses of the Nigerian state system, a new social compact needs to be negotiated between the state and civil society. In content, form, and process this must be an inclusive national dialogue. The new social compact should bring together key Nigerian actors and the international community in a synergy for democratic consolidation in Nigeria. Unlike previous pacts, which were intra-elite, the new pact should be broad-based so that people can identify with it and claim it as their own. This project would produce, in Nigerians, the spirit of consensus and commitment present in the Americans in 1787 when their union was forged.

An inclusive democratic process would allow for the development of consensus on major issues of national importance as well as expressions 
of disagreement. The principle behind this synergy can be stated as good governance and capacity-building for social justice and empowerment. It is only with such a social compact that Nigeria can be seen as a true federal state where democracy blossoms. Finally, in order to consolidate this pact, it is important to shift the focus from distributive politics, the popular demand for sharing the shrinking national cake, to productive politics, diversifying the economy to increase the size of the cake.

All constitutionalism demands a civic culture based on a fairly high level of popular education and a general shared belief in rules rather than power as a means for resolving conflict. Federalism, as exacting as constitutionalism, presupposes an additional measure of political tolerance and sense of responsibility. If the existence of such a civic culture cannot be counted on, the federal formula may not be viable. For a federation to be able to resist failure, the leaders, and their followers, must 'feel federal'. They must be moved to think of themselves as a people with one common self-interest, capable, where necessary, of overriding most other considerations of small group interest. It is not enough that units of a federation have the same ideal of 'the good' but that 'the good' for any one must be consciously subordinated to or compatible with 'the good for all'. This, then, is tantamount to an ideological commitment to the success of federalism. With such spirit, federalism will not only be seen as a means to gain independence or financial stability, as is the case with Nigeria, but as an end in itself.

\section{Bibliography}

Adekanye, J. B. (1992). Nigerian Tribune, September 14, 1992.

Akinkuotu, A. (2005). How Britain Rigged Elections, Census for the North. (Tell. No. 10 March 7, 2005).

Apter, D. E. (1964). (Ed.) Ideology and Discontent. New York: The Free Press of Glencoe.

Apter, D. E. (1965). Politics of Modernization. Chicago: Chicago University Press.

Arikpo, O. (1967). The Development of Modern Nigeria. Cambridge: Cambridge University Press. 
Awa, E. O. (1964). Federal Government in Nigeria. Berkeley: University of California Press.

Awa, E. O. (1976). Issues in Federalism. Benin: Ethiope Publishing Corporation.

Awa, E. O. (1993). Thoughts on Nigerian Federalism. The Guardian, April, 8-10.

Awolowo, O. (1947). Path to Nigerian Federalism. London: Oxford University Press.

Awolowo, O. (1968). The People's Republic. Ibadan: Oxford University Press.

Awolowo, O. (1968). Awo on the Nigerian Civil War. Ibadan: Ibadan University Press.

Elaigwu, I. J. (1985). Nation-Building and Political Development in Nigeria: The Challenge of Unity in a Heterogeneous Society', Proceedings of the National Conference on Nigeria since Independence, Vol. 1, Political Development. Zaria, Nigeria.

Gooby, P. T. (2015). UK Policy Community Viewing Ethnic Diversity Policy: From Stronger To Weaker Multi-Culturalism?. Jurnal Ilmiah Peuradeun, 3(2), 217-234.

Graham-Douglas, N. (1985). Echoes of June 12? Proceedings of the National Conference on Nigeria since Independence, Vol. 1, Political Development. Zaria, Nigerian

Haynes, J. (2015). Religion in Global Politics: Explaining Deprivatization. Jurnal Ilmiah Peuradeun, 3(2), 199-216.

Jagun, D. (1993). Nigeria: The Basis of Union. Lagos: The Guardian, April, 8, 1993.

Karibi, R. A. I. N. (2015). Religion, Human Rights and the Challenges of Freedom. Jurnal Ilmiah Peuradeun, 3(1), 39-54.

Linz, J. J. (1997). Democratization and Types of Democracies: New Task for Comparatives. Background paper for the Conference, "Democracy and Federalism". All Souls College. Oxford University.

Lvina, E. (2015). The Role of Cross-Cultural Communication Competence: Effective Transformational Leadership Across Cultures. Jurnal Ilmiah Peuradeun, 3(1), 1-18.

Morgan, J. H. (2014). Americanizing Islam as the Price of Assimilation. Jurnal Ilmiah Peuradeun, 2(2), 1-16.

Riker, W. (1997). Towards a New Comparative Analysis of Democracy andFederalism. In A. Stepan paper read at the conference on "Democracy and Federalism" All Souls College, Oxford University. 